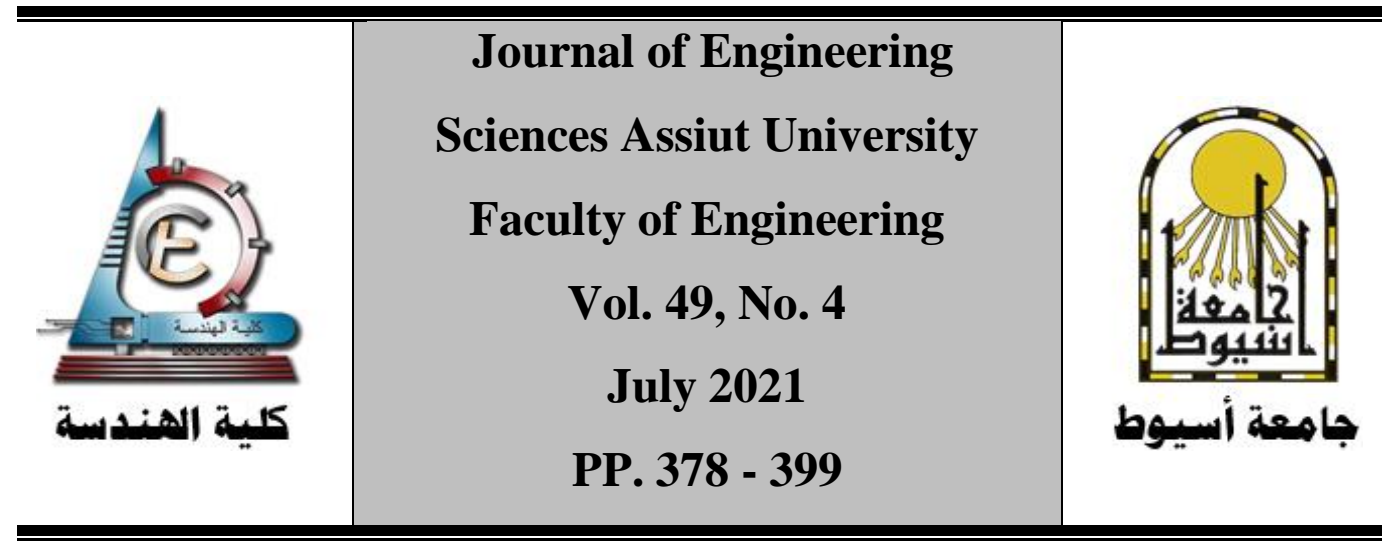

\title{
Evaluation of Hot Mix Asphalt and Binder Performance Modified with High Content of Nano Silica Fume
}

\section{Ali Y. Aboelmagd ${ }^{1}$, Ghada S. Moussa ${ }^{2}$, Mahmoud Enieb ${ }^{3}$, Safwan Khedr $^{4}$, El-Sayed M. Abd Alla ${ }^{5}$}

\footnotetext{
${ }^{1}$ Demonstrator, Department of Civil Engineering, Assiut University, Egypt ali_yousef@aun.edu.eg

${ }^{2}$ Associate Professor Department of Civil Engineering, Assiut University, Egypt ghada.moussa@aun.edu.eg

${ }^{3}$ Associate Professor Department of Civil Engineering, Assiut University, Egypt m.enieb@aun.edu.eg

${ }^{4}$ Professor, Dept of Construction Engineering, American University in Cairo, Egypt safkhedr@aucegypt.edu

${ }^{5}$ Professor Department of Civil Engineering, Assiut University, Egypt elsayed.mohamed1@eng.au.edu.eg
}

Received 2 April 2021; Revised 29 April 2021; Accepted 30 April 2021

\begin{abstract}
This research aims to evaluate the mechanical properties of hot asphalt mixtures prepared using modified asphalt binders with various contents of nano-silica fume (NSF). The modification to virgin bitumen is done by shear mixing with NSF at low contents $(2,4,6$, and $8 \%)$ and high contents $(20,30,40$, and 50\%) with bitumen weight. The homogeneity of the modified asphalts was assessed using Scanning Electron Microscopy. The rotational viscosity, softening point, and penetration tests were used to evaluate the rheological-physical properties of the modified asphalt binders. The stiffness, moisture damage, rutting, and fatigue of the hot mixes prepared with NSF-modified binders were evaluated using Marshall, indirect tensile strength, and double punching tests. The results showed a significant improvement in the rheological-physical properties of the modified binders with high content compared
\end{abstract}


to low content of NSF. Therefore, the modified binders with $30 \%, 40 \%$, and $50 \%$ of NSF were selected to prepare NSF-modified mixtures. The results showed that asphalt mixtures incorporating 30, 40, and 50\% NSF-modified binders were more resistant to moisture damage, rutting, and fatigue cracking compared to the control mixture. The novelty in this research is to produce a modified asphalt mixture with two-thirds a quantity of bitumen while achieving a high performance compared to the control mixture.

Keywords: Nanomaterial, Silica fume, Bitumen reduction, Asphalt mixture, Moisture susceptibility, Double punching, Rutting, Fatigue.

\section{Introduction}

Traffic volumes continue to increase coupled with fluctuations in environmental conditions causing a significant reduction in the service life of the pavement. To deal with such issues, an improvement in the asphalt mixture's performance is required to sustain the pavement service life while reducing the maintenance need. The asphalt binder (bitumen) represents a small content (about 5\%) among the components of the hot mix asphalt (HMA). However, it plays a vital role in the performance of HMA. The rheological and physical properties of asphalt binders significantly influence the behavior of HMA towards distresses [1]. Most virgin bitumen requires the use of additives to improve its properties to suit traffic intensity and different environmental conditions [2, $\underline{3}]$. Selecting a suitable enhancer varies from country to another depending on meteorological conditions and availability of materials. In addition, the performance improvement rate of modified asphalt should not be the only factor in selecting the suitable modifier, but some other factors such as economic factors, availability, and production technology should be taken into consideration when selecting an additive.

Among the bitumen modifiers, polymers were the most widely used ones. The results of polymer-modified bitumen showed improvements in the properties of asphalt binder. However, polymer-modified bitumen has many shortcomings such as storage stability. Where the polymer separates from the asphalt binder during the storage stage. Besides, the high cost associated with some types of polymers increases the final cost of road construction, this makes them unfeasible for large-scale application [4-8].

Recently, several researchers have investigated the binders modified with nanomaterials to create a modified asphalt that meets the engineering requirements for the construction of better flexible pavements, which the conventional asphalt cannot meet [9-15]. Researchers have found a significant improvement in the asphalt modified with nanomaterials, due to the large 
surface area of these materials $[16, \underline{17}]$. However, most of them have employed chemically prepared nanomaterials at exorbitant prices and limited quantities, making them unfeasible for a wide range of road projects. Therefore, the challenge here is to use nanomaterials prepared inexpensively and can be produced in large quantities for improving the properties of asphalt.

Silica fume (S.F) is a nanomaterial produced at high temperatures and available in large quantities. S.F is an industrial waste powder produced during the production of elemental silicon or alloys containing silicon [18-20]. S.F has been widely utilized to enhance the properties of building concrete, but limited research studies explored the effect of adding S.F on the properties of the asphalt mixture [20]. Al-taher et al. modified virgin bitumen using different contents of S.F (2, 4, 6 and $8 \%$ by bitumen weight). They concluded that S.F improved the rutting resistance and Marshall stability of the HMA mixture. At $6 \%$ of silica fume, the Marshall stability value increased by $23.6 \%$ and the rutting depth decreased by $36 \%$ compared to the conventional HMA mixture [21]. Shafabakhsh et al. evaluated the asphalt mixture prepared with silica fume modified binders at different contents $(3 \%, 5 \%, 7 \%$, and $10 \%$ by bitumen weight). Their results showed that silica fume enhanced the creep behavior of HMA at high stress and temperatures compared to the conventional asphalt mixture [22]. Abutalib et al. mixed silica fume with virgin bitumen at contents of 2,4 , and $8 \%$ by bitumen weight. They found that the silica fume-modified binder was less sensitive to temperature and more resistant to the effect of aging compared to the virgin binder [18]. In other studies, silica fume with contents of 2, 4, $6 \%$ by weight of binder was used to modify virgin bitumen. The results showed that the addition of SF improved the rheological-physical properties of the virgin bitumen [23-25].

As an industrial waste, the price of silica fume is relatively low compared to the traditional modifiers and virgin bitumen as well. While the average price of SF is $0.1 \mathrm{US} \mathrm{\$} \mathrm{/} \mathrm{kg}[26,27]$, the price of Egyptian virgin bitumen is around 0.35 US $\$ / \mathrm{kg}$ according to the Egyptian General Petroleum Corporation (EGPC) [28]. This promotes utilizing SF in the manufacturing of asphalt mixtures. However, limited research explored using silica fume in improving asphalt mixture. None of them investigated the effect of utilizing silica fume in high concentrations on the performance of the asphalt binder and mixture. Therefore, this study investigated the possibility of modifying the virgin bitumen with various contents of silica fume $(2,4,6,8,20,30,40$, and $50 \%$ by bitumen weight). Also, the fatigue, rutting, and moisture damage tendency of the silica fume modified-HMA mixture were evaluated. Where these distresses are significant in equatorial regions due to relatively high temperatures during the summer. 


\section{Materials and Samples Preparation}

\subsection{Asphalt binder}

A base bitumen was obtained from Alexandria Oil Company, Alexandria, Egypt, with the basic properties as following: the penetration depth at $25^{\circ} \mathrm{C}$ is $7.5 \mathrm{~mm}$, the softening point temperature is $50.5^{\circ} \mathrm{C}$, and the rotational viscosity at $135^{\circ} \mathrm{C}$ is $0.435 \mathrm{~Pa} . \mathrm{s}$ according to ASTM D5, D36, and D4402, respectively [29-31].

\subsection{Aggregates}

In this study, a blend of the three common types of aggregates was used to prepare all the asphalt mixtures. Crushed dolomite as coarse aggregates, siliceous sand resulting from crushed dolomite as a fine aggregate, and dolomite dust as a mineral filler. The bulk specific gravities of mineral filler, fine aggregate, and coarse aggregate were $2.5,2.501$, and 2.586 respectively (ASTM C127) [32]. The Loss Angeles abrasion and absorption percentages of coarse aggregate were $25 \%$ and $1.4 \%$ respectively (ASTM C131) [33]. The aggregate blend gradation was selected according to gradation limits of wearing coarse (Dense gradation 4C) set by the Egyptian Code for Urban and Rural Roads (ECP) [34]. The aggregates were separated on standard sieves then a specific weight was taken from each sieve to achieve the gradation of the standard blend. The aggregates blend gradation and the standard limits are listed in Table 1.

\subsection{Nano-silica fume}

Nano-silica fume (NSF) is a very fine powder that was produced by the Egyptian Ferro-Alloys Company (EFACO) as industrial waste material. According to the American Concrete Institute (ACI), "the silica fume is produced in electric arc furnaces of the production of elemental silicon or alloys containing silicon".

Table 2 lists the chemical and physical properties of the NSF. Figure 1(a) shows the general shape of the NSF. A Transmission Electron Microscope (TEM) was utilized to scan the NSF particles at the nanoscale. As shown in Figure 1(b), most NSF particles are in the range of 20 to $100 \mathrm{~nm}$. 
Table 1. Aggregates blend gradation and standard limits

\begin{tabular}{|c|c|c|}
\hline Sieve Size & Blending Passing $(\%)$ & Standard limits $(\%)[\underline{34}]$ \\
\hline $25.4 \mathrm{~mm}$ & 100 & 100 \\
\hline $19.51 \mathrm{~mm}$ & 90 & $80-100$ \\
\hline $9.51 \mathrm{~mm}$ & 70 & $60-80$ \\
\hline $4.76 \mathrm{~mm}$ & 57 & $48-65$ \\
\hline $2.38 \mathrm{~mm}$ & 43 & $35-50$ \\
\hline $0.595 \mathrm{~mm}$ & 25 & $19-30$ \\
\hline $0.297 \mathrm{~mm}$ & 18 & $13-23$ \\
\hline $0.149 \mathrm{~mm}$ & 10 & $7-15$ \\
\hline $0.074 \mathrm{~mm}$ & 5 & $3-8$ \\
\hline
\end{tabular}

Table 2. The physical and chemical properties of the Nano-silica fume*

\begin{tabular}{|c|c|c|}
\hline \\
\hline Property & Measured values & Limitations \\
\hline \multicolumn{3}{|c|}{ Physical properties } \\
\hline Particles size $(\mathrm{nm})$ & $20-100$ & $\operatorname{Max} 100$ \\
\hline Color & Light gray & --- \\
\hline Specific gravity & 2 & --- \\
\hline Bulk density $\left(\mathrm{kg} / \mathrm{m}^{3}\right)$ & 340 & $250-350$ \\
\hline \multicolumn{3}{|c|}{ Chemical properties } \\
\hline $\mathrm{SIO}_{2}$ & $97 \%$ & Min $92 \%$ \\
\hline $\mathrm{C}$ & $0.5 \%$ & $\operatorname{Max} 1 \%$ \\
\hline $\mathrm{Fe}_{2} \mathrm{O}_{3}$ & $0.5 \%$ & Max $1.5 \%$ \\
\hline $\mathrm{Al}_{2} \mathrm{O}_{3}$ & $0.2 \%$ & Max $1 \%$ \\
\hline $\mathrm{CaO}$ & $0.2 \%$ & Max $0.75 \%$ \\
\hline $\mathrm{MgO}$ & $0.5 \%$ & Max $1.0 \%$ \\
\hline $\mathrm{K}_{2} \mathrm{O}$ & $0.5 \%$ & $\operatorname{Max} 1.25 \%$ \\
\hline $\mathrm{Na}_{2} \mathrm{O}$ & $0.2 \%$ & $\operatorname{Max} 0.8 \%$ \\
\hline $\mathrm{SO}_{3}$ & 0.15 & Max $0.5 \%$ \\
\hline $\mathrm{Cl}$ & $<0.01 \%$ & $\operatorname{Max} 0.1 \%$ \\
\hline $\mathrm{H}_{2} \mathrm{O}$ & $0.5 \%$ & Max $0.5 \%$ \\
\hline PH-value (fresh) & 6 & $5.5-7.5$ \\
\hline
\end{tabular}

*According to the datasheet from the supplier. 


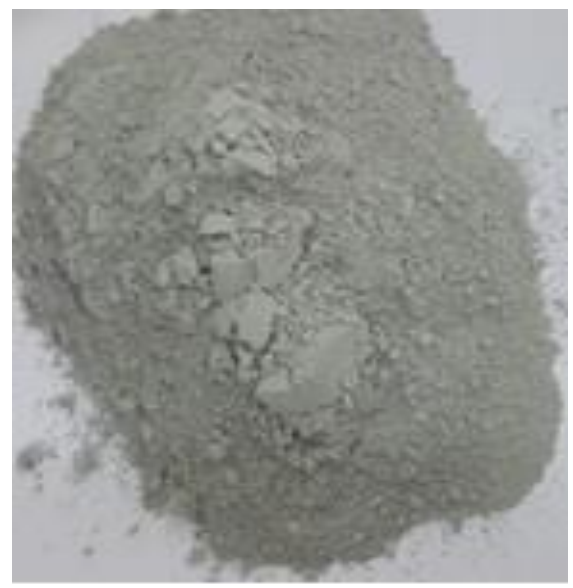

(a)

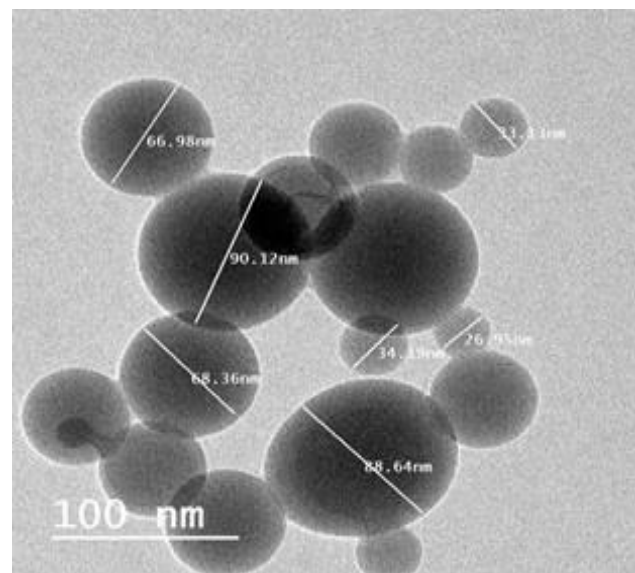

(b)

Figure 1. (a) The general shape of NSF, and (b) nanostructured particles of NSF

\subsection{Preparation of the NSF- modified binder}

The NSF- modified asphalt was prepared using low contents $(2 \%, 4 \%, 6 \%$, and $8 \%)$ and high contents $(20 \%, 30 \%, 40 \%$, and $50 \%)$ by bitumen weight. The base bitumen was mixed with NSF using a Silverson L5M-A high-speed shear mixer at a temperature of $160^{\circ} \mathrm{C}$ and a shearing speed of $2000 \mathrm{rpm}$ for $1 \mathrm{hr}[23$, 25]. The homogeneity of modified asphalts was assessed using Scanning Electron Microscopy.

\subsection{Preparation of compacted asphalt mixtures}

The binders modified with $30 \%, 40 \%$, and $50 \%$ of NSF were selected to prepare NSF-modified mixtures. The specific gravity of the base, 30, 40, and $50 \%$ NSF modified binder are 1.02, 1.17, 1.25, and 1.38, respectively (ASTM D70) [35]. The compacted Hot Mix Asphalt (HMA) samples were prepared according to Marshall's procedure (ASTM D6926) [36]. The mixing and compaction temperatures of HMA were computed according to the rotational viscosity standard for binders $(0.17 \pm 0.02 \mathrm{~Pa} . \mathrm{s}$ for mixing and $0.28 \pm 0.03$ Pa.s for compaction). All the mixtures were mixed at $170^{\circ} \mathrm{C}$ and compacted at $155^{\circ} \mathrm{C}$ to maintain the results comparable. The hot aggregates were mixed with four different percentages of the base and modified binders $(4.5,5,5.5$, and $6 \%$ ) until homogeneity is reached. The mixed specimens were compacted with 75 blows /side using a Marshall hammer to simulate heavy traffic volume. After at least $24 \mathrm{~h}$, the mixed samples were kept at room temperature for curing before any testing. The Marshall stability and flow were measured for all samples according to ASTM D6927. The bulk specific gravities of mixtures and maximum theoretical specific gravity were estimated according to ASTM 
D2726 to obtain the volumetric properties of Marshall samples (\%air voids, \% voids in the mineral aggregate, and \%voids filled with asphalt) [37]. The optimum asphalt content (OAC) for control and modified mixtures was estimated according to the Egyptian Code for Urban and Rural Roads (ECP) [34]. According to the requirements of the ECP, it has been concluded that $\mathrm{OAC}$ is $5.2 \%$ for the control and all modified mixtures. Therefore, the asphalt mixtures were fabricated with a $5.2 \%$ binder to evaluate the mechanistic properties of the HMA for control and modified mixtures.

\section{Experimental Program}

\subsection{Asphalt binder evaluation tests}

\subsubsection{Tests of rheological and physical properties}

The penetration test (ASTM D5), softening point test (ASTM D36), and rotational viscosity test (ASTM D4402), were used to evaluate the properties of the base and modified binders [29-31]. The Penetration Index (PI) was computed to assess the temperature sensitivity of binders. It can be calculated using the softening point and penetration at $25^{\circ} \mathrm{C}$ as presented in Equation (1) [38].

$$
\mathrm{PI}=\frac{(1952-500 \times \log (P 25)-20 \times \mathrm{SP})}{(50 \times \log (P 25)-S P-120)}
$$

Where SP is the softening point and P25 is the penetration value at $25^{\circ} \mathrm{C}$.

\subsection{Asphalt mixtures evaluation tests}

\subsubsection{Marshall test}

The control and NSF-modified mixtures were prepared at the same asphalt binder content (5.2\%). The Marshall parameters of control and NSF-modified mixtures were investigated to evaluate the effect of the NSF-modified binder on the properties of mixtures. The stability, flow, bulk density, and air voids of the asphalt mixtures were evaluated for all mixtures. Rigidity or Marshall Quotient (MQ) was estimated for all mixtures, where the MQ is the ratio of stability to flow value.

\subsubsection{Indirect tensile strength test}

Indirect tensile strength (ITS) test was performed according to ASTM D6931 to investigate the effect of moisture on the tensile strength of the control and NSF-modified mixtures [39]. The ITS can be calculated by applying a diagonal 
compressive load to standard Marshall samples. Six samples with air voids of $7 \pm 0.5 \%$ were prepared at OAC for each mixture. The samples were divided into two groups. For the first group, three samples were tested in a dry state at a temperature of $25^{\circ} \mathrm{C}$ with a loading rate of $50.8 \mathrm{~mm} /$ minute until failure of the samples. For the second group, the other three samples were conditioned in a water bath for $24 \mathrm{hrs}$ at $60{ }^{\circ} \mathrm{C}$ then $2 \mathrm{hrs}$ at $25^{\circ} \mathrm{C}$. The conditioned samples were tested with the same loading rate until failure of the samples. The ITS of conditioned and unconditioned compacted mixtures were calculated to estimate the tensile strength ratio (TSR). The ITS and TSR can be computed by using Equations (2) and (3), respectively. The TSR is used to investigate the moisture susceptibility of asphalt mixtures.

$\mathrm{ITS}=\frac{2000 \mathrm{P}}{\pi \mathrm{HD}}$

$\mathrm{TSR} \%=100\left(\frac{\mathrm{ITS}_{\mathrm{wet}}}{\mathrm{ITS}_{\mathrm{dry}}}\right)$

Where ITS is indirect tensile strength in $\mathrm{kPa}$; $\mathrm{P}$ is collapse load in $\mathrm{N}$; D is the diameter of the sample in $\mathrm{mm} ; \mathrm{H}$ is the thickness of the sample in $\mathrm{mm}$; TSR is

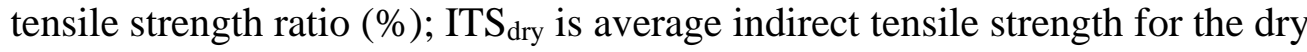
group of samples in $\mathrm{kPa}$; ITS $\mathrm{wet}_{\text {ws }}$ average indirect tensile strength for the conditioned group of samples in $\mathrm{kPa}$.

\subsubsection{Double punching test}

A double punching test (DPT) was performed to assess the fatigue and rutting behavior of the asphalt mixture [40]. Marshall cylindrical specimens (101.6 $\mathrm{mm}$ diameter and $63.5 \mathrm{~mm}$ height) were used to run this test. The cylindrical specimens were immersed in a water bath at $60^{\circ} \mathrm{C}$ for 30 mins immediately before testing to assess the rutting, while other specimens were tested at $20^{\circ} \mathrm{C}$ to assess the fatigue behavior of the asphalt mixture [40]. As shown in Figure 2 , the cylindrical specimen was placed in the center of two steel punches $(25$ $\mathrm{mm}$ diameter each) and then loaded vertically at a rate of $1.27 \mathrm{~mm} / \mathrm{min}$ until collapse. The average failure loads of three specimens for each mixture were used in estimating the tensile strength $\left(\sigma_{t}\right)$ as showed in Equation (4) [40-42].

$\sigma_{t}=\frac{P}{\pi\left(1.2 b H-a^{2}\right)}$ 
Where $\sigma_{\mathrm{t}}$ is tensile strength $\left(\mathrm{kg} / \mathrm{cm}^{2}\right), \mathrm{P}$ is collapse load $(\mathrm{kg}), \mathrm{b}$ is sample radius $(\mathrm{cm}), \mathrm{H}$ is sample height $(\mathrm{cm})$, and a is steel punch radius $(\mathrm{cm})$.

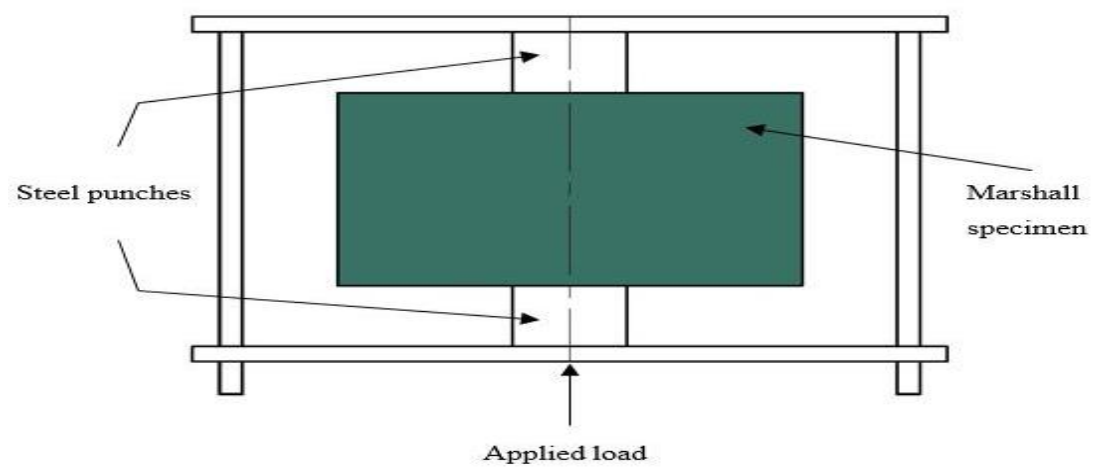

Figure 2 Double punch test Setup

\section{Results and analysis}

\subsection{Asphalt binders}

\subsubsection{Microstructural evaluation of modified binders}

A scanning electron microscope was used to evaluate the binder's homogeneity and quantify the dispersion of NSF within it. SEM images of the base and 40\% NSF modified asphalt are presented in Figure 3. As can be seen, the nanoparticles have been well dispersed within the binder. Moreover, the surface of the $40 \%$ NSF modified binder is more rough compared to the base asphalt indicating a difference in surface properties, which led to a difference in the physical properties between them [43].

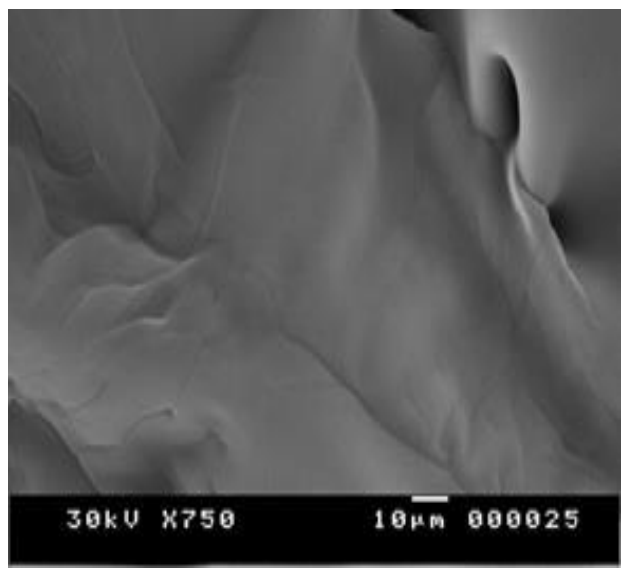

(a) Base asphalt

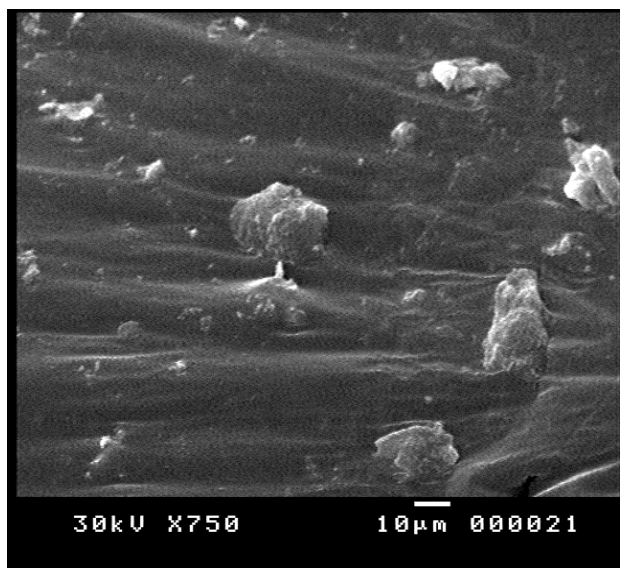

(b) $40 \%$ NSF modified binder

Figure 3. SEM images: (a) base asphalt and (b) $40 \%$ NSF modified binder 


\subsubsection{Rheological and Physical properties of modified binders}

Figure 4 shows the penetration values of the NSF-modified binder at different contents of NSF. As can be seen, the addition of NSF decreased the penetration values, which indicates increasing the hardness of the modified binder [12]. On the other hand, the softening point values increased with increasing the NSF contents as presented in Figure 5. The change of the physical properties was more significant at the high concentrations compared to low concentrations of NSF. This trend implies a lower temperature sensitivity and higher stiffness of the NSF-modified asphalts that are important properties, especially in the regions that have high temperature and heavy traffic [44].

The penetration index (PI) was used to evaluate the temperature sensitivity of the modified binders. The higher penetration index indicates a lower temperature sensitivity. The PI of asphalt binder used for road construction has been standard to be between +2.0 and -2.0 [45] .

Figure 6 shows the change in the PI values as a function of the NSF contents. As can be seen, the PI values of the binder modified with low concentrations of NSF are decreasing inconsistently with increasing the content of the NSF from $2 \%$ to $8 \%$. While the PI values increased when using high concentrations of NSF from $20 \%$ to $50 \%$. Where the PI values of modified asphalt with low NSF concentrations were negative values and the opposite occurred when using high NSF concentrations. This reveals a significant improvement in the temperature sensitivity of the binder modified with high NSF concentrations. As can be seen, all the PI values are within the acceptable range of -2.0 to +2.0 for asphalt binders used in pavement construction [12, 45].

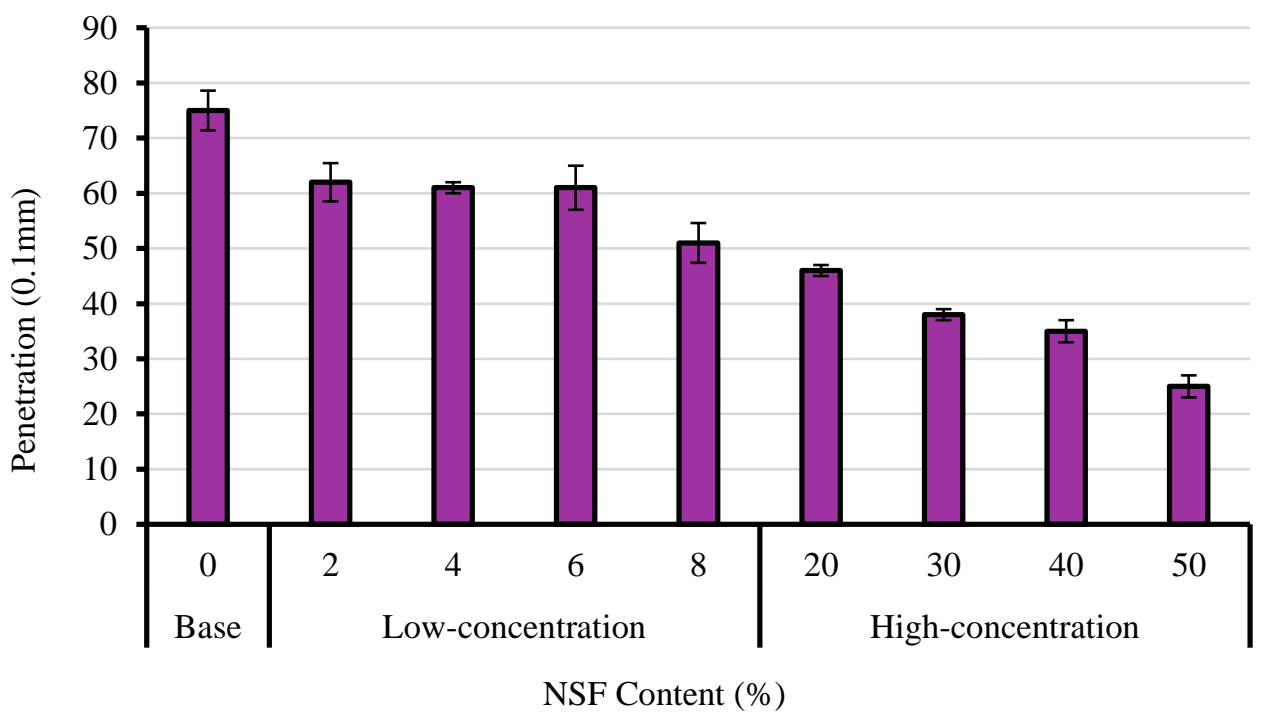

Figure 4. Penetration values of the base and NSF-modified binders 


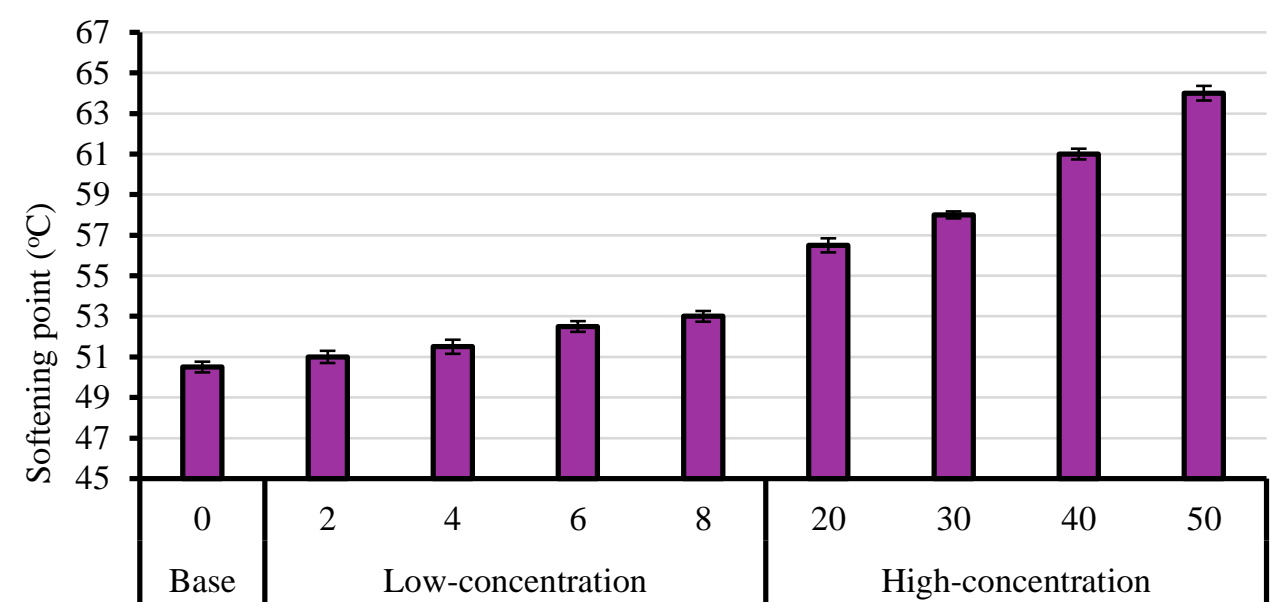

NSF Content (\%)

Figure 5. Softening point values of the base and NSF-modified binders

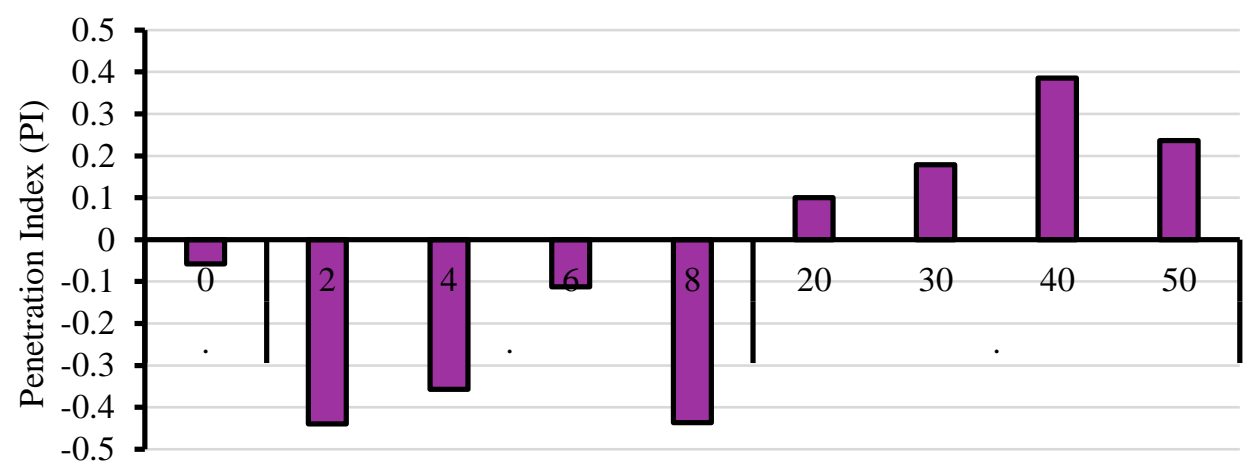

NSF Content $(\%)$

Figure 6. Penetration index values of the base and NSF-modified binders

The purpose of the rotational viscosity test at high temperatures (above 135 ${ }^{\circ} \mathrm{C}$ ) is to investigate the ability to pump the binder into the HMA manufacturing plant during the mixing and compaction [31]. The increase in viscosity always indicates a significant improvement in the rutting resistance of the binder [ 1 , $\underline{44}, \underline{46}$. The rotational viscosities values at a temperature of 135 and $165{ }^{\circ} \mathrm{C}$ for the base bitumen and NSF-modified asphalts at different contents of the NSF are presented in Figure 7. As can be seen, the addition of NSF increased the binder's viscosity at 135 and $165^{\circ} \mathrm{C}$. The results show that modified 
binders with high concentrations of NSF have the highest viscosity values, while there was no significant difference between the viscosity values of the low concentrations-modified binders and the base asphalt at 135 and $165^{\circ} \mathrm{C}$. Where the viscosity values at $135^{\circ} \mathrm{C}$ of the binders incorporating $30,40,50 \%$ NSF were higher than the base asphalt by 229,358 , and $570 \%$, respectively. As can be seen, the rotational viscosity values at $135^{\circ} \mathrm{C}$ for all NSF-modified binders satisfied the Superpave limit of $3000 \mathrm{cP}$ or less according to AASHTO M 320 [47].

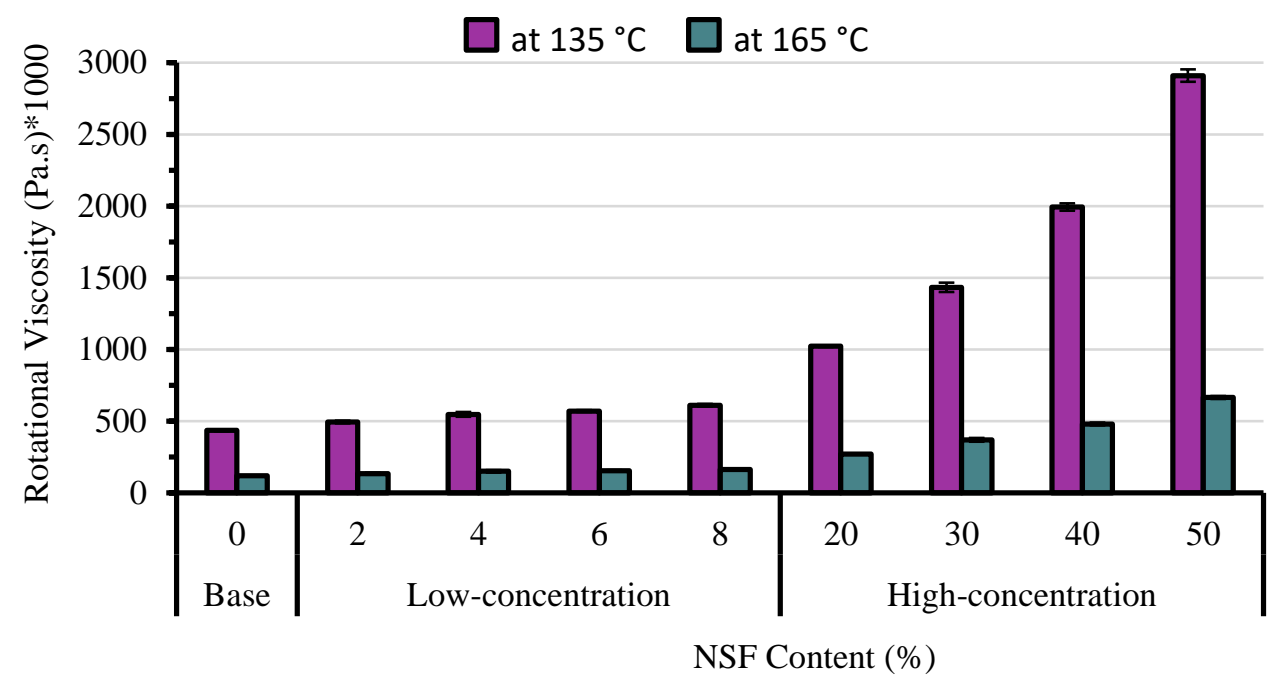

Figure 7. Rotational viscosity values of the base and NSF-modified binders

\subsection{Compacted asphalt mixtures}

The results of binder evaluation tests showed a significant improvement in the physical-rheological properties of the binder modified with high contents compared to low contents of NSF. Therefore, the binders modified with 30\%, $40 \%$, and $50 \%$ of NSF were selected to prepare NSF-modified mixtures.

\subsubsection{Stiffness of asphalt mixtures}

Figure 8 shows Marshall stability and flow of the control and modified HMA mixtures. As can be seen, the stability and flow values of all HMA mixtures comply with the Egyptian standards of more than $900 \mathrm{~kg}$ and (2-4) $\mathrm{mm}$, respectively [34]. As can be seen, the addition of NSF significantly increased the stability of HMA mixtures. Where the stability value of the mixtures incorporating 30,40,50\% NSF-modified binder was higher than the control mixture by 54,83 , and $88 \%$, respectively. This indicates that the HMA mixtures incorporating NSF-modified asphalt are more resistant to rutting [48]. 
Figure 9 presents the volumetric properties of control and modified HMA mixtures. As can be seen, the air voids percentage (AV\%) of mixtures prepared using NSF-modified asphalt are slightly higher compared to the control mixtures, this may be due to the higher specific gravity of NSF-modified binder compared to the base binder. However, all AV\% values of control and modified mixtures within the limits (3 to 5\%) set by ECP [34]. As shown, the voids percentage in the mineral aggregate (VMA\%) and voids percentage filled with asphalt (VFA\%) of modified mixtures are slightly less than the control mixture. It is noted that the VMA\% and VFA\% values for control and modified mixtures comply with the asphalt institute standards of more than $13 \%$ and $(65-75 \%)$, respectively [49].

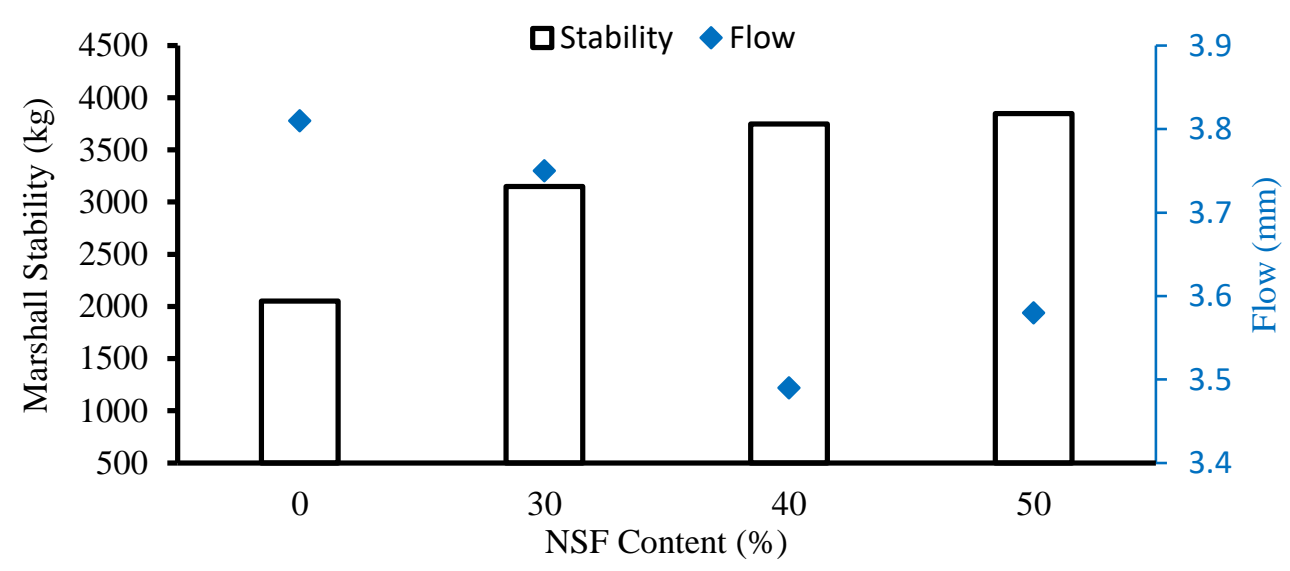

Figure 8. Marshall stability and flow values of control and modified HMA mixtures

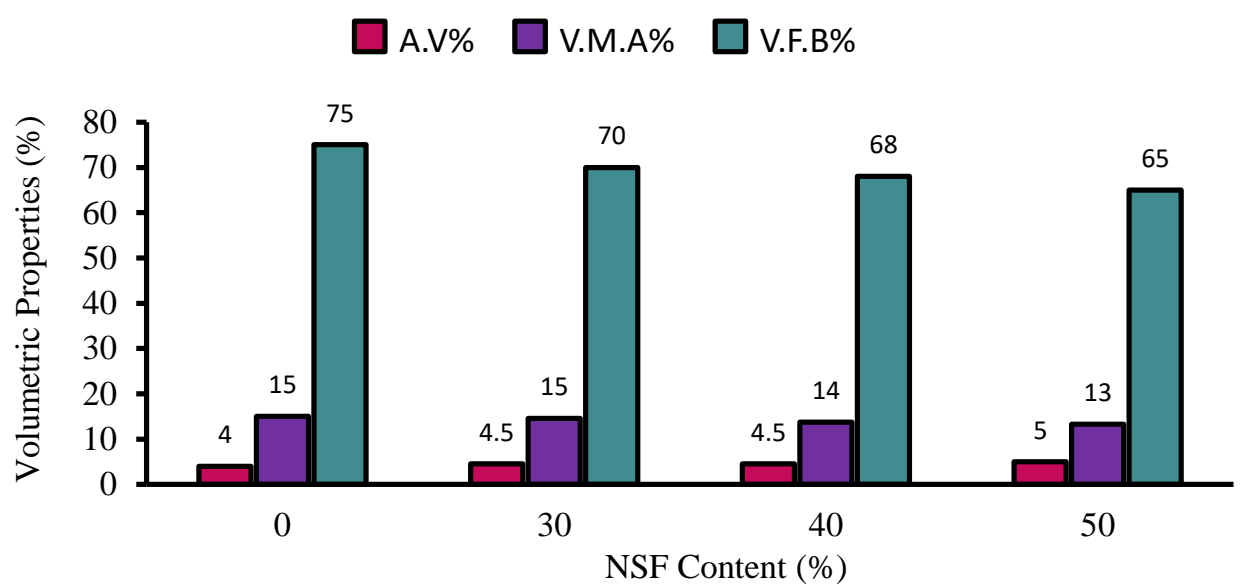

Figure 9. Volumetric properties of control and modified HMA mixtures 
Marshall Quotient (MQ) or Rigidity values were computed by dividing the stability by the flow of HMA mixtures. The MQ is an indicator of the rutting of HMA mixtures, higher MQ indicates higher resistance of permanent deformation (deceased rutting tendency) [ㄱ, 50]. As shown in Figure 10, it can be noted that increasing NSF contents significantly increased the mixture rigidity, where the MQ value of the control mixture increased by $56,99,100 \%$ when using 30, 40, and 50\% NSF-modified binder, respectively. This indicates that the mixtures incorporating NSF-modified asphalt are more resistant to permanent deformation and appropriate for heavy traffic volume requirements [51].

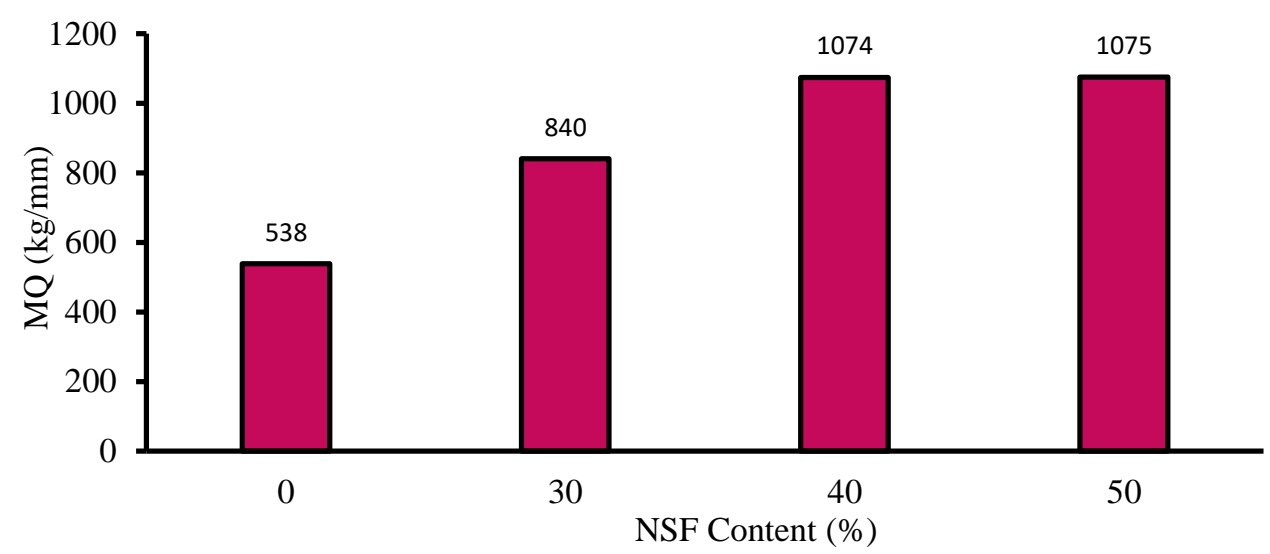

Figure 10. Marshall Quotient (MQ) values of control and modified HMA mixtures

\subsubsection{Moisture damage and stripping resistance of asphalt mixtures}

The indirect tensile strength (ITS) and the tensile strength ratios (TSR) values of the control and NSF-modified mixtures are showed in Figure 11. The results showed a slight increase in the ITS values of the modified mixtures for dry and wet samples compared to the control mixture. However, the TSR of the control mixture increased with increasing the NSF content. This indicates that the mixtures incorporating NSF-modified asphalt are more resistant to moisture damage compared to the control mixture [12]. Moreover, the bonding between the aggregates and NSF- modified binder was improved, and consequently higher stripping resistance was obtained. However, only the 50\% NSFmodified mixture satisfied the minimum value of TSR (80\%) set by the Egyptian code of practice [34].

\subsubsection{Rutting behavior of asphalt mixtures}

The double punching test (DPT) is a viable alternative test for evaluating the asphalt mixture's rutting $[40,52, \underline{53}]$. Where the tensile strength $\left(\sigma_{t}\right)$ computed by DPT at $60^{\circ} \mathrm{C}$ is an indicator for the rutting of HMA mixtures, higher $\sigma_{t}$ indicates lower the rutting of asphalt mixtures [40]. Figure 12 presents the 
tensile strength values of the control and NSF-modified asphalt mixtures at $60^{\circ} \mathrm{C}$. As can be seen, the addition of NSF significantly increased the tensile strength of HMA mixtures. Where the tensile strength values of the mixtures incorporating 30,40, and 50\% NSF-modified binder were higher than the control mixture by 105,205 , and $247 \%$, respectively. The significant increase in tensile strength at $60^{\circ} \mathrm{C}$ of NSF-modified mixtures indicates a great improvement in pavement resistance to permanent deformations and stripping susceptibility [41]. This promotes using the NSF-modified mixers in hot regions or heavy traffic areas.

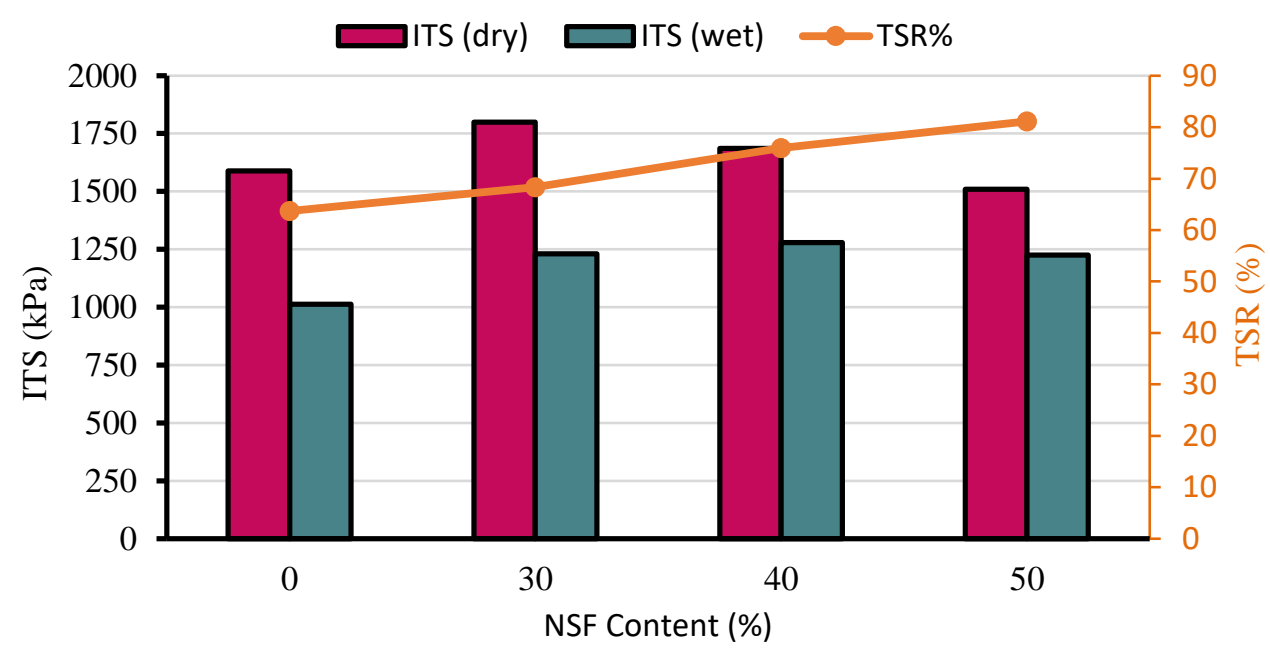

Figure 11. Moisture damage resistance of control and modified HMA mixtures

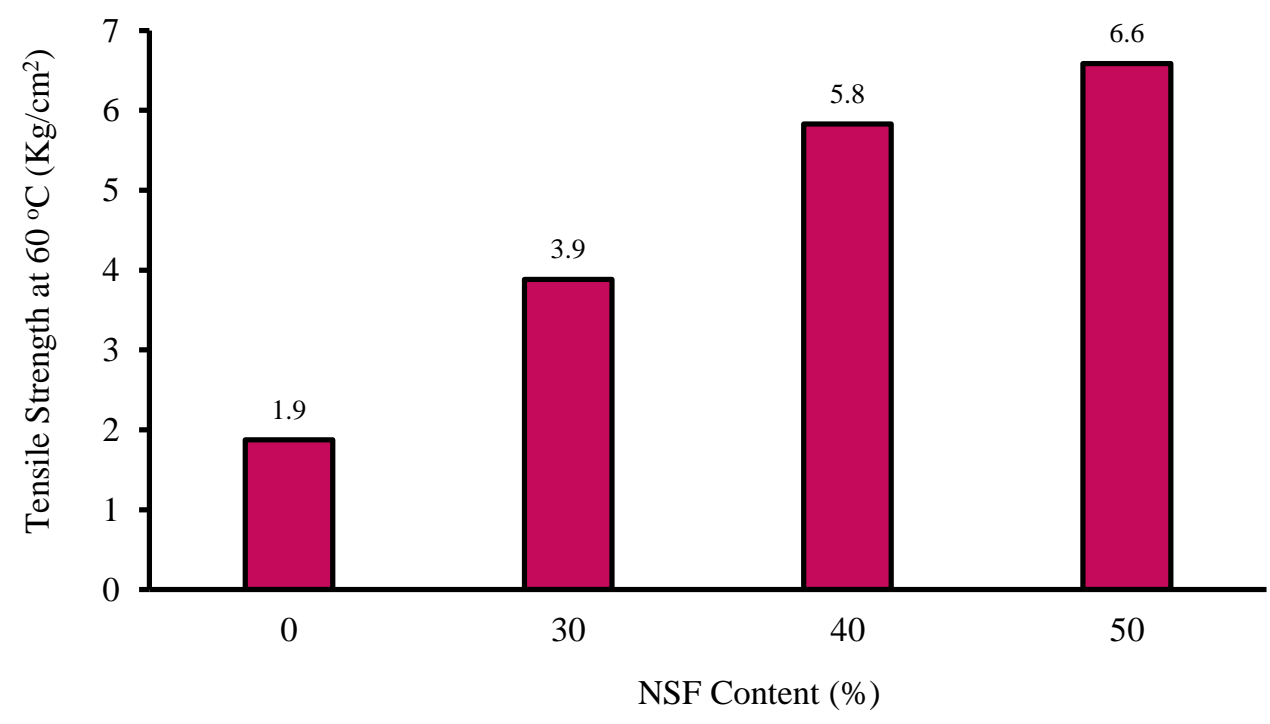

Figure 12.The tensile strength at $60^{\circ} \mathrm{C}$ as indicator for asphalt mixture's rutting 


\subsubsection{Fatigue behavior of asphalt mixtures}

The double punching test (DPT) is a viable surrogate test for quantifying the asphalt mixture's fatigue. Where the tensile strength $\left(\sigma_{t}\right)$ computed by DPT at $20^{\circ} \mathrm{C}$ is an indicator for the fatigue behavior of HMA mixtures, higher $\sigma_{t}$ indicates reduced cracking in asphalt mixtures resulting from fatigue [40]. The HMA mixture that has a high $\sigma_{\mathrm{t}}$ is expected to demonstrate a high ability to absorb the energy without fracture [54]. Figure 13 shows the tensile strength values of the control and NSF-modified asphalt mixtures at $20^{\circ} \mathrm{C}$. The result showed a significant increase in tensile strength of HMA mixtures with increasing NSF content. Where the $\sigma_{\mathrm{t}}$ of control mixture increased by 26, 32, and $51 \%$ when using the asphalt binder modified with 30,40 , and $50 \%$ NSF, respectively. This indicates a significant improvement in the resistance of the NSF-modified mixtures to fatigue cracking [40].

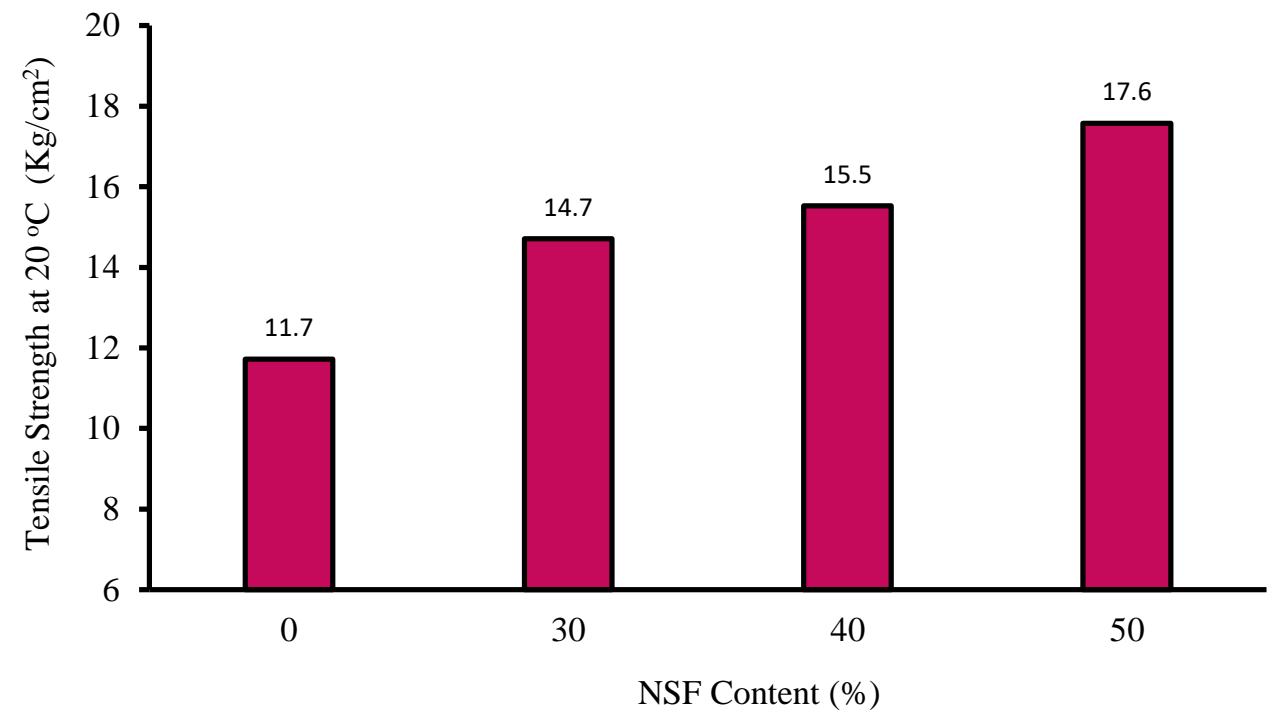

Figure 13. The tensile strength at $20^{\circ} \mathrm{C}$ as indicator for asphalt mixture's fatigue

\section{Conclusions}

The general conclusions from this study were as follow:

- Results showed an improvement in the physical properties of the NSFmodified asphalt with increasing in its stiffness and a decrease in its susceptibility to temperature compared to the base binder.

- Asphalt mixes prepared with 30, 40, and 50\% NSF-modified binders have the same optimum asphalt content as the control mixture, which leads to 
the use of fewer quantities of virgin bitumen for economical pavement construction.

- The adding of NSF as a binder-modifier significantly increased the Marshall Quotient of asphalt mixtures, thus mixtures incorporating NSFmodified asphalt are more resistant to permanent deformation and suitable for heavy traffic volume requirements.

- The mixtures incorporating NSF-modified binder are more resistant to moisture damage compared to the control mixture. Moreover, the bonding between aggregate and NSF-modified binder was improved, and consequently higher stripping resistance was obtained.

- The addition of NSF increased the tensile strength of the asphalt mixtures at $60{ }^{\circ} \mathrm{C}$ indicating a significant improvement in the pavement resistance to rutting. This promotes the use of NSF-modified mixers in hot regions or heavy traffic areas.

- The result showed a significant increase in the tensile strength of asphalt mixtures at $20^{\circ} \mathrm{C}$ with increasing NSF content. This indicates a significant improvement in the resistance of the NSF-modified mixtures to fatigue cracking.

\section{References}

[1] M. Zahid, Mrinal, Takumi,, "Evaluation of viscosity and rutting properties of nanoclay-modified asphalt binders," in Geo-Congress 2014: Geocharacterization and Modeling for Sustainability, 2014, pp. 3695-3702.

[2] S. K. Maram Saudy, "Evaluation of normal and modified asphalt according to conventional and modern grading systems," DOI: 10.14455/ISEC.res.2016.58, Proceedings of the First European and Mediterranean Structural Engineering and Construction, At Istanbul, Turkey, 2016.

[3] S. Lv, L. Hu, C. Xia, M. B. Cabrera, Y. Guo, C. Liu, et al., "Recycling fish scale powder in improving the performance of asphalt: A sustainable utilization of fish scale waste in asphalt," Journal of Cleaner Production, vol. 288, p. 125682, 2021.

[4] P. H. Yeh, Y. H. Nien, J. H. Chen, W. C. Chen, and J. S. Chen, "Thermal and rheological properties of maleated polypropylene modified asphalt," Polymer Engineering \& Science, vol. 45, pp. 1152-1158, 2005.

[5] G. Polacco, P. Kř́̌ž, S. Filippi, J. Stastna, D. Biondi, and L. Zanzotto, "Rheological properties of asphalt/SBS/clay blends," European Polymer Journal, vol. 44, pp. 3512-3521, 2008.

[6] N. I. M. Yusoff, A. A. S. Breem, H. N. Alattug, A. Hamim, and J. Ahmad, "The effects of moisture susceptibility and ageing conditions on nano-silica/polymermodified asphalt mixtures," Construction and Building Materials, vol. 72, pp. 139-147, 2014. 
[7] G. Moussa, A. Abdel-Raheem, and T. Abdel-Wahed, "Investigating the moisture susceptibility of asphalt mixtures modified with high-density polyethylene," JES. Journal of Engineering Sciences, vol. 48, pp. 765-782, 2020.

[8] Y. M. Alghrafy, E.-S. M. Abd Alla, and S. M. El-Badawy, "Phase angle master curves of sulfur-extended asphalt modified with recycled polyethylene waste," Innovative Infrastructure Solutions, vol. 6, p. 84, 2021/01/21 2021.

[9] S. Karahancer, M. Enieb, M. Saltan, S. Terzi, E. Eriskin, A. Cengizhan, et al., "Evaluating mechanical properties of bitumen and hot mix asphalt modified with nano ferric oxide," Construction and Building Materials, vol. 234, p. 117381, 2020.

[10] M. Saltan, S. Terzi, and S. Karahancer, "Performance analysis of nano modified bitumen and hot mix asphalt," Construction and Building Materials, vol. 173, pp. 228-237, 2018.

[11] M. Saltan, S. Terzi, and S. Karahancer, "Examination of hot mix asphalt and binder performance modified with nano silica," Construction and Building Materials, vol. 156, pp. 976-984, 2017.

[12] M. Enieb and A. Diab, "Characteristics of asphalt binder and mixture containing nanosilica," International Journal of Pavement Research and Technology, vol. 10, pp. 148-157, 2017.

[13] H. Ezzat, S. El-Badawy, A. Gabr, E.-S. I. Zaki, and T. Breakah, "Evaluation of asphalt binders modified with nanoclay and nanosilica," Procedia engineering, vol. 143, pp. 1260-1267, 2016.

[14] F. S. Bhat and M. S. Mir, "Performance evaluation of nanosilica-modified asphalt binder," Innovative Infrastructure Solutions, vol. 4, p. 63, 2019/11/19 2019.

[15] A. W. Oda, A. El-Desouky, H. Mahdy, and O. M. Moussa, "Effects of asphalt modification by Nanosilica and Nanoclay on asphalt binder and hot mix asphalt properties," in IOP Conference Series: Materials Science and Engineering, 2020, p. 012003.

[16] F. C. Martinho and J. P. S. Farinha, "An overview of the use of nanoclay modified bitumen in asphalt mixtures for enhanced flexible pavement performances," Road Materials and Pavement Design, vol. 20, pp. 671-701, 2017.

[17] J. Crucho, L. Picado-Santos, J. Neves, and S. Capitão, "A Review of Nanomaterials' Effect on Mechanical Performance and Aging of Asphalt Mixtures," Applied Sciences, vol. 9, p. 3657, 2019.

[18] N. Abutalib, E. H. Fini, S. Aflaki, and T. M. Abu-Lebdeh, "Investigating effects of application of silica fume to reduce asphalt oxidative aging," American Journal of Engineering and Applied Sciences, vol. 8, pp. 176-184, 2015.

[19] T. C. Holland, Silica fume user's manual: Federal Highway Administration, 2005. 
[20] X. Zheng, W. Xu, H. Feng, and K. Cao, "High and Low Temperature Performance and Fatigue Properties of Silica Fume/SBS Compound Modified Asphalt," Materials, vol. 13, p. 4446, 2020.

[21] M. G. Al-Taher, H. D. Hassanin, M. F. Ibrahim, and A. M. Sawan, "Investigation of the Effect of Adding Silica Fume on Asphalt Concrete Properties," International Journal of Engineering Research, vol. 7, pp. 48-55, 2018.

[22] G. Shafabakhsh, O. J. Ani, and S. Mirabdolazimi, "Experimental investigation on rutting performance of microsilica modified asphalt mixtures," International Journal of Engineering Research \& Technology (IJERT), vol. 4, pp. 371-378, 2015.

[23] H. H. Zghair, H. H. Joni, and M. S. Hassan, "Evaluation of the effect of mixing conditions of micro-silica modified asphalt binder," in IOP Conference Series: Materials Science and Engineering, 2019, p. 022048.

[24] H. H. Zghair, H. H. Joni, and M. S. Hassan, "Influence of micro-size silica powder on physical and rheological characteristics of asphalt binder," International Journal of Engineering \& Technology, vol. 7, pp. 180-184, 2018.

[25] H. H. Zghair, H. H. Joni, and M. S. Hassan, "Evaluating The Effects of Micro and Nano Size of Silica Filler on Asphalt Cement Properties," Engineering and Technology Journal, vol. 38, pp. 1832-1841, 2020.

[26] O. A. Ahmad, "Production of high-performance silica fume concrete," American journal of applied sciences, vol. 14, pp. 1031-1038, 2017.

[27] R. Bajpai, K. Choudhary, A. Srivastava, K. S. Sangwan, and M. Singh, "Environmental impact assessment of fly ash and silica fume based geopolymer concrete," Journal of Cleaner Production, vol. 254, p. 120147, 2020/05/01/ 2020.

[28] EGPC, "Egyptian General Petroleum Corporation," http://www.egpc.com.eg/, 2021.

[29] ASTM D5 / D5M-20, "Standard Test Method for Penetration of Bituminous Materials," ASTM International, West Conshohocken, PA, 2020.

[30] ASTM D36 / D36M-14(2020), "Standard Test Method for Softening Point of Bitumen (Ring-and-Ball Apparatus)," in ASTM International, West Conshohocken, PA, 2020.

[31] ASTM D4402 / D4402M-15, "Standard Test Method for Viscosity Determination of Asphalt at Elevated Temperatures Using a Rotational Viscometer," in ASTM International, West Conshohocken, PA, 2015.

[32] ASTM C127-15, "Standard Test Method for Relative Density (Specific Gravity) and Absorption of Coarse Aggregate," ASTM International, West Conshohocken, PA, 2015.

[33] ASTM C131 / C131M-20, " Standard Test Method for Resistance to Degradation of Small-Size Coarse Aggregate by Abrasion and Impact in the Los Angeles Machine," ASTM International, West Conshohocken, PA, 2020. 
[34] Housing and Building National Research Center, "Egyptian Code of Practice for Urban and Rural Roads-Part 4. Road Material and Its Tests," Housing and Building National Research Center: Cairo, Egypt, 2008.

[35] ASTM D70 / D70M-21, "Standard Test Method for Specific Gravity and Density of Semi-Solid Asphalt Binder (Pycnometer Method)," ASTM International, West Conshohocken, PA, 2021.

[36] ASTM D6926-20, "Standard Practice for Preparation of Asphalt Mixture Specimens Using Marshall Apparatus," ASTM International, West Conshohocken, PA, 2020.

[37] ASTM D2726 / D2726M-19, " Standard Test Method for Bulk Specific Gravity and Density of Non-Absorptive Compacted Asphalt Mixtures," ASTM International, West Conshohocken, PA, 2019.

[38] J. W. Read, David,, The shell Bitumen Handbook: Thomas Telford,, 2003.

[39] ASTM D6931-17, "Standard Test Method for Indirect Tensile (IDT) Strength of Asphalt Mixtures," ASTM International, West Conshohocken, PA, 2017.

[40] H. Wen, S. Bhusal, and X. Li, "Double punch test: simple performance test to evaluate the fatigue and rutting potential of asphalt concrete," Journal of Materials in Civil Engineering, vol. 25, pp. 645-652, 2013.

[41] G. S. Moussa, A. Abdel-Raheem, and T. Abdel-Wahed, "Effect of Nanoclay Particles on the Performance of High-Density Polyethylene-Modified Asphalt Concrete Mixture," Polymers, vol. 13, p. 434, 2021.

[42] R. A. Jimenez, "Testing for debonding of asphalt from aggregates," 1973.

[43] D. Risović, S. M. Poljaček, K. Furić, and M. Gojo, "Inferring fractal dimension of rough/porous surfaces - A comparison of SEM image analysis and electrochemical impedance spectroscopy methods," Applied Surface Science, vol. 255, pp. 3063-3070, 2008.

[44] I. Amin, S. M. El-Badawy, T. Breakah, and M. H. Ibrahim, "Laboratory evaluation of asphalt binder modified with carbon nanotubes for Egyptian climate," Construction and Building Materials, vol. 121, pp. 361-372, 2016.

[45] M. Greysmith, Bituminous Materials in Road Construction: HM Stationery Office, 1962.

[46] Y. M. Alghrafy, E.-S. M. Abd Alla, and S. M. El-Badawy, "Rheological properties and aging performance of sulfur extended asphalt modified with recycled polyethylene waste," Construction and Building Materials, p. 121771, 2020.

[47] AASHTO-M320, "Standard Method of Test for Performance Graded Asphalt Binder," American Association of State and Highway Transportation Officials: Washington, DC, USA, 2016.

[48] M. O. Azzam, Z. Al-Ghazawi, and A. Al-Otoom, "Incorporation of Jordanian oil shale in hot mix asphalt," Journal of Cleaner Production, vol. 112, pp. 22592277, 2016. 
[49] Asphalt Institute, Mix design methods for asphalt concrete and other hot-mix types: Asphalt Institute, 1969.

[50] B. V. Kok and M. Yilmaz, "The effects of using lime and styrene-butadienestyrene on moisture sensitivity resistance of hot mix asphalt," Construction and building materials, vol. 23, pp. 1999-2006, 2009.

[51] M. Hasaninia and F. Haddadi, "The characteristics of hot mixed asphalt modified by nanosilica," Petroleum Science and Technology, vol. 35, pp. 351-359, 2017.

[52] L. F. Walubita, A. N. Faruk, L. Fuentes, A. Prakoso, S. Dessouky, B. Naik, et al., "Using the Simple Punching Shear Test (SPST) for evaluating the HMA shear properties and predicting field rutting performance," Construction and Building Materials, vol. 224, pp. 920-929, 2019.

[53] A. N. Faruk, S. I. Lee, J. Zhang, B. Naik, and L. F. Walubita, "Measurement of HMA shear resistance potential in the lab: The Simple Punching Shear Test," Construction and Building Materials, vol. 99, pp. 62-72, 2015.

[54] M. Enieb, A. Diab, and X. Yang, "Short- and long-term properties of glass fiber reinforced asphalt mixtures," International Journal of Pavement Engineering, vol. 22, pp. 64-76, 2021/01/02 2021. 


\section{تقييم أداء المخلوط والرابط الاسفلتي المعدل بتركيزات عالية

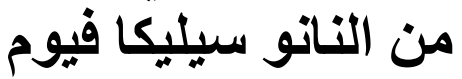

مع زيادة الوعي البيئي أصبح اعاده استخدام النفايات الصناعية هو الحل الأمثل لتجنب

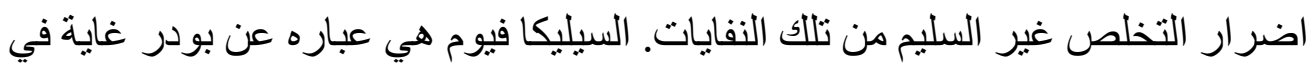
النعومة، و هي عباره عن ماده ثانويه وجدت داخل افران تصنيع السبائك الحديدية. تز امنا

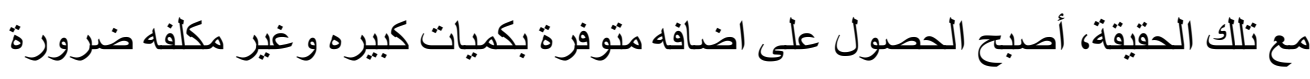
ملحه لتحسين خو اص البيتومين و الحفاظ على كمياته غير المتجددة. ولذلك فان الهدف من هذا البحث هو تقييم الخواص الميكانيكية للخلطات الإسفلتية الساخنة المحضرة باستخدام الر ابط الاسفلتي المعدل بالنانو سيليكا فيوم. تم خلط البيتومن البكر الناتج من

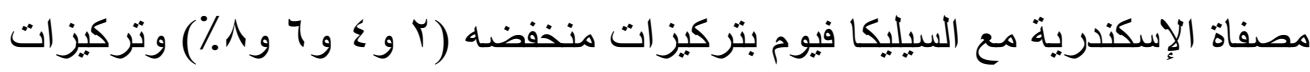

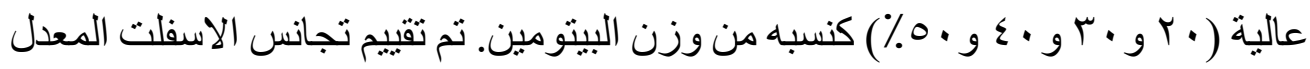

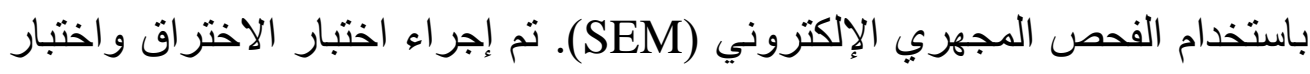

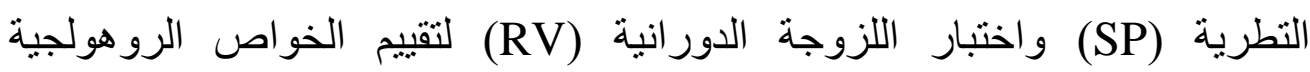

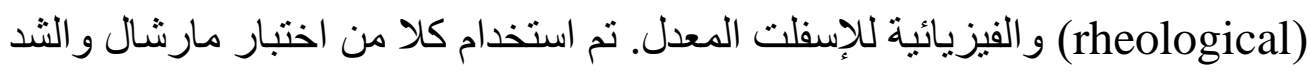

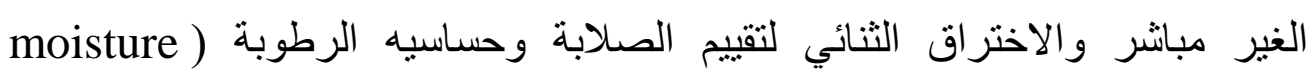

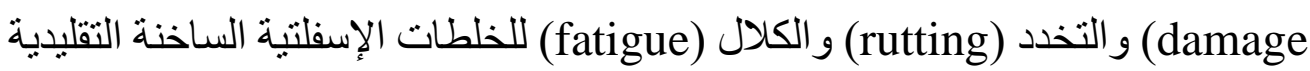

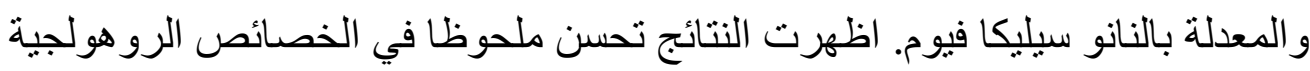

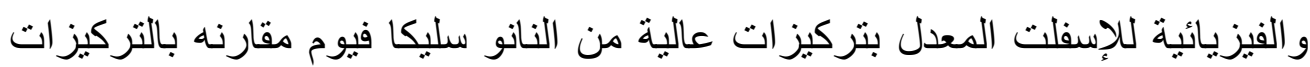

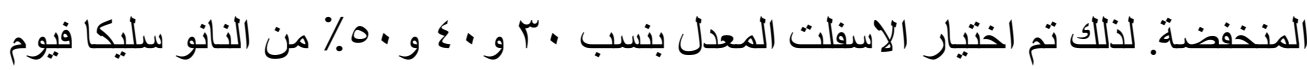

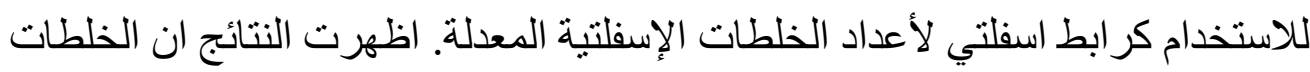

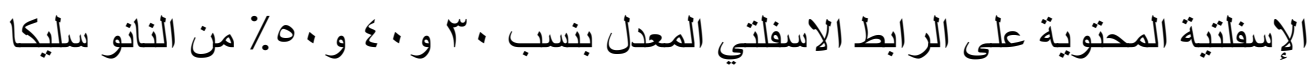
فيوم أكثر مقاو مه للتخدد و الكلال و الرطوبة إذا ما قورنت مع الخلطات الإسفلتية التقليدية. الجديد في هذا البحث هو انتاج خلطات اسفلتيه باستخدام رابط اسفلتي ثلثيه بيتو مين و التلث الأخر نانو سيليكا فيوم مع تحقيق خصائص ميكانيكية وفيزيائية جيدة لتلك الخلطات مقارنه بالخلطة التقليدية. 